\title{
Parasitic helminth fauna of tree frogs from cocoa plantations at Ugboke, Edo State, Nigeria
}

\author{
Edo-Taimo*, 0. and Aisien, M.S.0. \\ Department of Animal and Environmental Biology, Faculty of Life Sciences, University of Benin, P.M.B. 1154, Benin City, Nigeria \\ *Correspondence: omoyemwen.edo-taiwo@uniben.edu; https://doi.org/10.52417/njls.v11i1.13
}

\begin{abstract}
Cocoa pods are vulnerable to pest and diseases which often cause huge financial losses to farmers. To address this challenge and improve yield, cocoa farmers often resort to pesticide application on the cocoa trees. This leads to deposition of pesticides residues on the cocoa trees, the undergrowth and plantations floor with devastating consequences for amphibians including tree frogs. Previous studies have reported the immune suppressive nature of pesticides on anurans thereby rendering them more susceptible to infection. This study is part of an on-going investigation of the effect of pesticide application on the pattern of helminth parasitic infections of anurans in pesticide-treated cocoa plantations at Ugboke, Edo State. A total of 354 tree frogs belonging to three genera (Leptopelis, Hyperolius and Afrixalus), consisting of 14 species were examined. A high species richness $(\mathrm{d}=1.971)$ and diversity $\left(H^{\prime}=2.215\right)$ was recorded. Ten species $(71.43 \%)$ of these frogs were infected while four $(28.57 \%)$ were uninfected. The overall prevalence of parasitic infections was $30.23 \%$. Thirteen helminth parasites including three cestodes, two digeneans and eight nematode species were recovered. A significantly higher $(\mathrm{P}<0.05)$ prevalence of infection was recorded during the wet season $(31.64 \%)$ than in the dry $(10.53 \%)$. There was high parasite diversity with low prevalence and infection intensity of infection as previously reported for other anurans collected from the same cocoa plantations.
\end{abstract}

Keywords: Tree frogs, helminth parasites, cocoa plantations, pesticides, Edo State

\section{Introduction}

Plantations are large expanses of land with trees cultivated for commercial purposes. The cultivation process involves clearing a vast portion of the natural vegetation, and replacement with the desired crop, resulting in deforestation and habitat fragmentation. Often times, some of the plantations are exposed to chemical contamination from herbicides, fungicides and pesticides. For example, cocoa plantations are subjected to periodic spraying with pesticides, especially during the wet season, to prevent or combat pest and disease infestations. Cocoa pods are vulnerable to pests (e.g. myriads and stem borer) and diseases (e.g. black pod and cocoa swollen shoot virus). These pests and diseases cause huge financial losses of as much as $30 \%$ or even more in severe cases to farmers (David, 2005). Residues of the pesticides applied are deposited on tree tops (branches and leaves), the undergrowth and leaf litter on the plantation floor, which are respectively micro-habitats for different species of frogs.

Apart from their direct toxicity on anuran hosts, they are also known to affect the immune system of exposed tadpoles, resulting in higher prevalence of helminth infections in adult frogs (Kiesecker, 2002; Rohr et al., 2008). Pesticide-contaminated environments are also known to reduce the survival/infectivity of free-living stages of parasitic helminths, resulting in reduced infection intensity (Lafferty and Kuris, 1999; Morley et al., 2003; Peitrock and Marcogliese, 2003).

Tree frogs are anurans that have their abode/dwellings on tree tops, shrubs and herbs in the undergrowth of the forest. They live and reproduce in the arboreal microhabitats, though they sometimes visit the ground in search of food and mates. They can be heard often making con-specific mating calls from these plants, especially those over hanging or close to water bodies.

This report is part of a study undertaken to determine the helminth parasites of amphibians from cocoa plantations at Ugboke, Edo State (Edo-Taiwo, 2018). Two previous publications from this study have dealt with the parasitic infections of leaf litter frogs (Edo-Taiwo and Aisien, 2020a) and ground dwelling anurans (Edo-Taiwo and Aisien, $2020 \mathrm{~b}$ ) from these plantations. The present paper is focused on the helminth parasites of tree frogs collected from these cocoa plantations.
The only report available on the helminth parasites of tree frogs in Nigeria is the work of Imasuen et al. (2012a), at Okomu National Park (a protected sanctuary for flora and fauna). The aim of this paper is to report on the helminths parasitic infections in the tree frogs from the pesticide/herbicide-contaminated environment in the cocoa plantations, comparing them with those from non-contaminated habitats.

\section{Materials and Methods}

Tree frog specimens were sampled from a number of contiguous cocoa plantations (6032'20" and 6045'35' $\mathrm{N}$ and 5015'20" and 5017'46"'E) at Ojo Camp-Ugboke of Usen, in Ovia South-West Local Government Area of Edo State, Nigeria. The cocoa plantations are traversed by streams and rivulets. Pesticides used for pest controls include Gammalin, Avesthrin (Cypermethrin 10\% EC), Scorpion, Best, Instakill and Ridonul Gold 66WP while Weed crusher was employed as herbicide. According to the farmers, the cocoa trees were sprayed weekly during the wet season; there was no pesticide application during the dry season.

The frogs were sampled at night (between $19.00 \mathrm{hrs}$ and $01.00 \mathrm{hrs}$ ) by active searches using the Visual Acoustic Encounter Surveys method (Crump and Scott, 1994) for 15 months (August 2012 - October 2013) covering both the wet and dry seasons. Collected specimens were identified following the protocols of Roedel $(2000,2007)$ and Schiotz (1963, 1999). The frogs were thereafter euthanized with Benzocaine solution (Goater et al., 1987; Muzzall, 1991) and the snout-vent length (SVL) taken before dissection. Sex determination was either by visual inspection (for vocal sacs in males) or after dissection (for gonads). The gastro-intestinal tract (oesophagus/stomach, small intestine, large intestine/rectum), body cavity, liver/gall bladder, lungs, heart and the urinary bladder were examined for parasites. The parasites recovered were processed according to Aisien et al. (2001). Strigeoid metacercariae were incubated in $0.85 \%$ normal saline containing $0.5 \%$ trypsin at $37^{\circ} \mathrm{C}$ in order to free the juvenile parasite. Parasites were examined with a 
binocular microscope and identified with the aid of appropriate keys (Yamaguti, 1961, 1971; Prudhoe and Bray, 1982; Khali et al., 1994) to the lowest possible taxon. Prevalence and mean intensity of parasitic infection among the tree frogs were calculated for each parasite taxon recovered (Bush et al., 1997). Alpha diversity indices were used to estimate species richness and diversity. Chi-square test was used to compare prevalence of infection between males and females; and between wet and dry seasons.

\section{Results}

Fourteen species of tree frogs belonging to two families (Arthroleptidae and Hyperoliidae) and three genera (Leptopelis, Hyperolius and Afrixalus) were examined in this study for helminth infections. Among these were Leptopelis occidentalis (08), L. spiritusnoctis (10), Leptopelis sp. (03), Hyperolius concolor (47), H. fusciventris (01), H. fusciventris burtoni (91), H. picturatus (22), H. sylvaticus (01), Hyperolius spp. 1-4 (66, 01, 52 and 01, respectively), Afrixalus dorsalis (50) and $A$. nigeriensis (01). The species richness (d) and diversity ( $\left.\mathrm{H}^{\prime}\right)$ were 1.971 and 2.215 , respectively.

Infection was recorded in 10 species $(71.43 \%)$ of the frogs while four (28.57\%) were uninfected. The uninfected tree frog species included H. fusciventris, H. sylvaticus, Hyperolius sp. 2 and $A$. nigeriensis. The overall prevalence of infection among the tree frogs was $30.23 \%$ (Table 1). The Hyperoliids were more infected $(30.63 \%)$ than the Arthroleptids $(28.57 \%)$, but this difference was not significant $(p>0.05)$

Thirteen helminth parasites were recovered from various predilection sites in the tree frogs (Table 2). The parasites included three species of cestodes (Cylindrotaenia jaegerskioeldi, larval Proteocephalus spp. 1 and 2), two digeneans (Ostioloides rappiae and a strigeoid trematode larva) and eight nematode species (Amplicaecum sp., Aplectana sp., Camallanus sp., Cosmocerca ornata, Cosmocerca sp., Foleyellides sp., Physaloptera sp. and an unidentified oxyurid nematode).

Table 1: Overall prevalence and mean intensity of parasitic infection in tree frogs from cocoa plantations at Ugboke

\begin{tabular}{lccccc}
\hline Species & $\begin{array}{c}\text { Number } \\
\text { examined }\end{array}$ & $\begin{array}{c}\text { Number } \\
\text { infected }\end{array}$ & $\begin{array}{c}\text { Prevalence } \\
(\%)\end{array}$ & $\begin{array}{c}\text { Number of } \\
\text { parasites }\end{array}$ & $\begin{array}{c}\text { Mean } \\
\text { intensity }\end{array}$ \\
\hline Arthroleptidae & 08 & 01 & 12.5 & 05 & 5.0 \\
L. occidentalis & 10 & 02 & 20.0 & 08 & 4.0 \\
L. spiritusnoctis & 03 & 02 & 66.7 & 10 & 5.0 \\
Leptopelis sp. & 47 & 10 & 21.3 & 20 & 2.0 \\
Hyperoliidae & 01 & - & - & - & - \\
H. concolor & 91 & 25 & 27.5 & 147 & 5.88 \\
H. fusciventris & 22 & 02 & 9.1 & 10 & 5.0 \\
H. fusc. burtoni & 01 & - & - & - & - \\
H. picturatus & 66 & 33 & 50.0 & 277 & 8.39 \\
H. sylvaticus & 01 & - & - & - & - \\
Hyperolius sp. 1 & 52 & 19 & 36.5 & 140 & 7.37 \\
Hyperolius sp. 2 & 01 & 01 & 100.0 & 01 & 1.0 \\
Hyperolius sp. 3 & 50 & 12 & 24.0 & 75 & 6.25 \\
Hyperolius sp. 4 & 01 & - & - & - & - \\
A. dorsalis & 354 & 107 & 30.23 & 693 & 6.48 \\
A. nigeriensis & & & & & \\
Total & & & & & \\
\hline
\end{tabular}

The most infected micro-habitat was the small intestine (in 16 hosts with 9 parasite species) with prevalence ranging from 1.2 to $66.7 \%$ (mean intensity, 1.0 to 36.0). The least preferred site was the oesophagus (Table 2). Cylindrotaenia jaegerskioeldi, Proteocephalus sp. 2, 0. rappiae, the strigeoid trematode larva, Aplectana sp., Foleyellides sp. and Physalopterasp. were generalists, infecting 3 to 7 hosts. Proteocephalus sp. 1, Amplicaecum sp., Camallanus sp., C. ornata, Cosmocerca sp. and the unidentified oxyurid nematode infected a single host each. Aplectana sp. was the most recurrent parasite encountered, occurring in seven host species with prevalence ranging from 1.1 to $12.5 \%$ (MI, 1.0 to 6.0), followed by Proteocephalus sp. 2

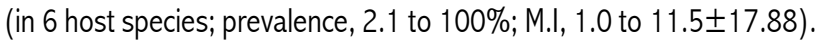
A total of 322 male and 34 female tree frogs were examined in this study. Prevalence of infection was higher in male tree frogs than in the female, but the difference was not significant $(P>0.05)$. Parasites were recovered from $99(30.75 \%)$ male and $08(23.53 \%)$ female frogs. Prevalence and intensity of infection of the different helminth parasites in relation to sex of the tree frogs is presented in Table 3 . Twelve $(92.3 \%)$ helminth species were recorded in the males and six $(46.2 \%)$ in the females. Three cestodes (C. jaegerskioeldi, larval
Proteocephalus spp. 1 and 2) occurred in male tree frogs; only one ( $C$. jaegerskioeldl) was recorded in a female of $H$. fusciventris burtoni (Table 3). The two digeneans encountered in this study were recorded in both sexes. Ostioloides rappiae infected different Hyperolius spp. with the highest prevalence and intensity of infection occurring in the female of Hyperolius fusciventris burtoni. Although the strigeiod trematode larva had its highest prevalence $(31.8 \%)$ in male Hyperolius sp. 1, the highest intensity $(12.5 \pm 3.54)$ occurred in $A$. dorsalis. With respect to nematode parasites, Amplicaecum sp, Camallanus sp., Cosmocerca sp., Foleyellides sp. and the unidentified oxyurid nematode infected only male frogs while $C$. ornata was recorded only in the females of $A$. dorsalis (Table 3 ). Both sexes of tree frogs were infected with Aplectana sp. and Physaloptera sp. Prevalence of infection was significantly higher $(\mathrm{P}<0.05)$ during the wet season $(31.64 \%)$ than in the dry $(10.53 \%)$. Almost all $(91.7 \%)$ the parasites species were recorded during the wet season with the exception of Amplicaecum sp. which incidentally was recorded only in the dry season (Table 4). Infection was recorded in all frogs during the wet season except in Hyperolius sp. 4. Only a few frogs harboured infections in the dry season (Table 4) 
Nig. J. Life Sc. 11(1\&2): 2021

Table 2: Prevalence and mean intensity of endohelminth parasites of tree frogs from cocoa plantations at Ugboke

\begin{tabular}{|c|c|c|c|c|}
\hline Parasite & Host & Predilection Site & Prevalence (\%) & Mean intensity \pm S.D \\
\hline \multicolumn{5}{|l|}{ Cestoda } \\
\hline \multirow[t]{6}{*}{ C. jaegerskioeldi } & A. dorsalis & Small intestine & 2.0 & 3.0 \\
\hline & H. fusc. burtoni & Small intestine & 4.4 & $2.0 \pm 1.16$ \\
\hline & H. picturatus & Small intestine & 4.6 & 7.0 \\
\hline & Hyperolius sp. 1 & Small intestine & 13.6 & $3.2 \pm 1.72$ \\
\hline & Hyperolius sp. 3 & Small intestine & 1.9 & 1.0 \\
\hline & Leptopelis sp. & Small intestine & 66.7 & $4.0 \pm 2.83$ \\
\hline Proteocephalus sp. 1 & Hyperolius sp. 1 & Attached to S.I \& Liver & 1.5 & 1.0 \\
\hline \multirow[t]{6}{*}{ Proteocephalus sp. 2} & A. dorsalis & Attached to liver & 6.0 & $4.7 \pm 3.97$ \\
\hline & H. concolor & Attached to liver & 2.1 & 1.0 \\
\hline & H. fusc. burtoni & Attached to liver & 4.4 & $11.5 \pm 17.88$ \\
\hline & H. picturatus & Attached to liver & 4.6 & 3.0 \\
\hline & Hyperolius sp. 3 & Attached to liver & 19.2 & $1.2 \pm 0.81$ \\
\hline & Hyperolius sp. 4 & $\begin{array}{l}\text { Attached to liver \& } \\
\text { stomach }\end{array}$ & 100.0 & 1.0 \\
\hline \multicolumn{5}{|l|}{ Digenea } \\
\hline \multirow[t]{4}{*}{ Ostioloides rappiae } & Hyperolius sp. 1 & Small intestine & 1.5 & 1.0 \\
\hline & Hyperolius sp. 3 & Small intestine & 3.9 & $2.0 \pm 1.41$ \\
\hline & H. fusc. burtoni & Small intestine & 1.2 & 6.0 \\
\hline & H. concolor & Small intestine & 4.3 & $1.5 \pm 0.71$ \\
\hline \multirow[t]{4}{*}{ Strigeiod trematode } & A. dorsalis & Large intestine & 4.0 & 12.5 \\
\hline & H. fusc. burtoni & Body cavity & 15.4 & 6.0 \\
\hline & Hyperolius sp. 3 & Body cavity & 17.3 & 5.3 \\
\hline & Hyperolius sp. I & Body cavity & 31.8 & 10.5 \\
\hline \multicolumn{5}{|l|}{ Nematode } \\
\hline Amplicaecum sp. & Leptopelis sp. & Small intestine & 33.3 & 2.0 \\
\hline \multirow[t]{7}{*}{ Aplectana sp. } & A. dorsalis & Small intestine & 10.0 & $5.6 \pm 3.21$ \\
\hline & H. concolor & Small \& Large intestine & 2.1 & 6.0 \\
\hline & Hyperolius sp. 3 & Large intestine/rectum & 3.8 & $6.0 \pm 7.07$ \\
\hline & L. occidentalis & Small \& Large intestine & 12.5 & 5.0 \\
\hline & L. spiritusnoctis & Large intestine/rectum & 10.0 & 2.0 \\
\hline & Hyperolius sp. 1 & Large intestine/rectum & 4.5 & 1.0 \\
\hline & H. fusc. burtoni & Large intestine/rectum & 1.1 & 2.0 \\
\hline Camallanussp. & H. concolor & Large intestine/rectum & 2.1 & 1.0 \\
\hline Cosmocercasp. & Hyperolius sp. 3 & Small intestine & 1.9 & 5.0 \\
\hline C. ornata & A. dorsalis & Large intestine/rectum & 2.0 & 4.0 \\
\hline \multirow[t]{5}{*}{ Foleyellides sp. } & A. dorsalis & Body cavity & 2.0 & 1.0 \\
\hline & H. concolor & Small intestine & 8.5 & $1.5 \pm 0.58$ \\
\hline & H. fusc. burtoni & Body cavity & 1.1 & 1.0 \\
\hline & Hyperolius sp. 1 & Body cavity & 4.5 & $6.0 \pm 8.66$ \\
\hline & Hyperolius sp. 3 & Body cavity & 1.9 & 22.0 \\
\hline \multirow[t]{3}{*}{ Physaloptera sp. } & H. concolor & Small intestine & 4.3 & $1.5 \pm 0.71$ \\
\hline & Hyperolius sp. 1 & Oesophagus/stomach & 3.0 & $2.5 \pm 2.12$ \\
\hline & L. spiritusnoctis & Oesophagus/stomach & 11.1 & 6.0 \\
\hline Oxyurid nematode & Hyperolius sp. 3 & Small intestine & 1.9 & 36.0 \\
\hline
\end{tabular}


Table 3: Prevalence and mean intensity of parasitic helminths based on sex of tree frogs from Ugboke cocoa plantations

\begin{tabular}{|c|c|c|c|c|c|}
\hline \multirow[t]{2}{*}{ Parasite } & \multirow[t]{2}{*}{ Hosts } & \multicolumn{2}{|c|}{ Male } & \multicolumn{2}{|c|}{ Female } \\
\hline & & $\begin{array}{c}\text { Prevalence } \\
(\%)\end{array}$ & $\mathrm{Ml} \pm \mathrm{S} . \mathrm{D}$ & $\begin{array}{c}\text { Prevalence } \\
(\%)\end{array}$ & $M I \pm S . D$ \\
\hline \multicolumn{6}{|l|}{ Cestoda } \\
\hline \multirow[t]{6}{*}{ C. jaegerskioeldi } & A. dorsalis & 2.3 & 3.0 & - & - \\
\hline & H. fusc. burtoni & 3.9 & $1.7 \pm 1.16$ & 7.1 & 3.0 \\
\hline & H. picturatus & 5.6 & 7.0 & - & - \\
\hline & Hyperolius sp. 1 & 13.6 & $3.2 \pm 1.72$ & - & - \\
\hline & Hyperolius sp. 3 & 2.0 & 1.0 & - & - \\
\hline & Leptopelis sp. & 66.7 & $4.0 \pm 2.83$ & - & - \\
\hline Proteocephalus sp. 2 & Hyperolius sp. 1 & 1.5 & 1.0 & - & - \\
\hline \multirow[t]{6}{*}{ Proteocephalus sp. 3} & A. dorsalis & 7.0 & $4.7 \pm 3.97$ & - & - \\
\hline & H. concolor & 2.2 & 1.0 & - & - \\
\hline & H. fusc. burtoni & 5.2 & $11.0 \pm 17.38$ & - & - \\
\hline & H. picturatus & 5.6 & 3.0 & - & - \\
\hline & Hyperolius sp. 3 & 20.0 & $1.2 \pm 0.45$ & - & - \\
\hline & Hyperolius sp. 4 & 100 & 1.0 & - & - \\
\hline \multicolumn{6}{|l|}{ Digenea } \\
\hline \multirow[t]{4}{*}{ 0. rappiae } & Hyperolius sp. 1 & 1.5 & 1.0 & - & - \\
\hline & Hyperolius sp. 3 & 4.0 & $2.0 \pm 1.41$ & - & - \\
\hline & H. fusc. burtoni & - & - & 7.1 & 6.0 \\
\hline & H. concolor & 4.4 & $1.5 \pm 0.71$ & - & - \\
\hline \multirow[t]{4}{*}{ Strigeiod trematode larva } & A. dorsalis & 4.7 & $12.5 \pm 3.54$ & - & - \\
\hline & H. fusc burtoni & 14.3 & $7.2 \pm 11.37$ & 21.4 & $2.0 \pm 1.00$ \\
\hline & Hyperolius sp. 3 & 20.0 & $7.0 \pm 6.27$ & - & - \\
\hline & Hyperolius sp. I & 31.8 & $10.5 \pm 35.48$ & - & - \\
\hline Nematode & & & & & - \\
\hline Amplicaecum sp. & Leptopelis sp. & 33.3 & 2.0 & - & - \\
\hline \multirow[t]{7}{*}{ Aplectana sp. } & A. dorsalis & 11.6 & $5.6 \pm 3.21$ & - & - \\
\hline & Hyperolius sp. 3 & 4.0 & $6.0 \pm 7.07$ & - & - \\
\hline & H. concolor & - & - & 50.0 & 6.0 \\
\hline & Hyperolius sp. 1 & 4.5 & 1.0 & - & - \\
\hline & H. fusc. burtoni & 1.3 & 2.0 & - & - \\
\hline & L. occidentalis & 16.7 & 5.0 & - & - \\
\hline & L. spiritusnoctis & 14.3 & 2.0 & - & - \\
\hline Camallanus sp. & H. concolor & 2.2 & 1.0 & - & - \\
\hline Cosmocercasp. & Hyperolius sp. 3 & 2.0 & 5.0 & - & - \\
\hline C. ornata & A. dorsalis & - & - & 14.3 & 4.0 \\
\hline \multirow[t]{5}{*}{ Foleyellides sp. } & A. dorsalis & 2.3 & 1.0 & - & - \\
\hline & H. concolor & 8.9 & $1.5 \pm 0.58$ & - & - \\
\hline & H. fusc. burtoni & 1.3 & 1.0 & - & - \\
\hline & Hyperolius sp. 1 & 4.5 & $6.0 \pm 8.66$ & - & - \\
\hline & Hyperolius sp. 3 & 2.0 & 22.0 & - & - \\
\hline \multirow[t]{3}{*}{ Physaloptera sp. } & H. concolor & 4.4 & $1.5 \pm 0.71$ & - & - \\
\hline & Hyperolius sp. 1 & 3.0 & $2.5 \pm 2.12$ & - & - \\
\hline & L. spiritusnoctis & - & - & 333 & 6.0 \\
\hline Oxyurid nematode & Hyperolius sp. 3 & 2.0 & 36.0 & - & - \\
\hline
\end{tabular}


Nig. J. Life Sc. 11(1\&2): 2021

Table 4: Seasonal prevalence and intensity of infection of parasitic endohelminths in tree frogs from Ugboke cocoa plantations

\begin{tabular}{|c|c|c|c|c|c|}
\hline \multirow[t]{2}{*}{ Parasite } & \multirow[t]{2}{*}{ Hosts } & \multicolumn{2}{|c|}{ Wet } & \multicolumn{2}{|c|}{ Dry } \\
\hline & & $\begin{array}{c}\text { Prevalence } \\
(\%)\end{array}$ & $\begin{array}{c}\text { Mean } \\
\text { intensity } \\
\pm \text { S.D }\end{array}$ & $\begin{array}{c}\text { Prevalence } \\
(\%)\end{array}$ & $\begin{array}{c}\text { Mean } \\
\text { intensity } \\
\pm \text { S.D }\end{array}$ \\
\hline \multicolumn{6}{|l|}{ Cestoda } \\
\hline \multirow[t]{6}{*}{ C. jaegerskioeldi } & A. dorsalis & 2.3 & 3.0 & - & - \\
\hline & H. fusc. Burtoni & 4.7 & $2.0 \pm 1.16$ & - & - \\
\hline & H. picturatus & 2.3 & 7.0 & - & - \\
\hline & Hyperolius sp. 1 & 13.6 & $3.2 \pm 1.72$ & - & - \\
\hline & Hyperolius sp. 3 & 2.0 & 1.0 & - & - \\
\hline & Leptopelis sp. & 50.0 & 6.0 & 100 & 2.0 \\
\hline Proteocephalus sp. 2 & Hyperolius sp. 1 & 1.5 & 1.0 & - & - \\
\hline \multirow[t]{6}{*}{ Proteocephalus sp. 3} & A. dorsalis & 6.8 & $4.7 \pm 3.97$ & - & - \\
\hline & H. concolor & 2.2 & 1.0 & - & - \\
\hline & H. fusc. burtoni & 4.7 & $11.5 \pm 18.06$ & - & - \\
\hline & H. picturatus & 4.6 & 3.0 & - & - \\
\hline & Hyperolius sp. 3 & 19.2 & $1.2 \pm 0.45$ & - & - \\
\hline & Hyperolius sp. 4 & - & - & 100 & 1.0 \\
\hline \multicolumn{6}{|l|}{ Digenea } \\
\hline \multirow[t]{4}{*}{ O. rappiae } & Hyperolius sp. 1 & 1.5 & 1.0 & - & - \\
\hline & Hyperolius sp. 3 & 3.9 & $2.0 \pm 1.41$ & - & - \\
\hline & H. fusc. burtoni & 1.2 & 6.0 & - & - \\
\hline & H. concolor & 4.4 & $1.5 \pm 0.71$ & - & - \\
\hline \multirow[t]{4}{*}{ Strigeiod trematode larva } & A. dorsalis & 4.5 & $12.5 \pm 3.54$ & - & - \\
\hline & H. fusc. burtoni & 16.5 & $6.1 \pm 10.22$ & - & - \\
\hline & Hyperolius sp. 3 & 19.2 & $7.0 \pm 6.27$ & - & - \\
\hline & Hyperolius sp. 1 & 31.8 & $10.5 \pm 35.48$ & - & - \\
\hline Nematode & & & & - & - \\
\hline Amplicaecum sp. & Leptopelis sp. & - & - & 100 & 2.0 \\
\hline \multirow[t]{7}{*}{ Aplectana sp. } & A. dorsalis & 11.4 & $5.6 \pm 3.21$ & - & - \\
\hline & Hyperolius sp. 3 & 3.8 & $6.0 \pm 7.07$ & - & - \\
\hline & H. concolor & 2.2 & 6.0 & - & - \\
\hline & Hyperolius sp. 1 & 4.5 & 1.0 & - & - \\
\hline & H. fusc. burtoni & 1.2 & 2.0 & - & - \\
\hline & L. occidentalis & 12.5 & 5.0 & - & - \\
\hline & L. spiritusnoctis & 12.5 & 2.0 & - & - \\
\hline Camallanus sp. & H. concolor & 2.2 & 1.0 & - & - \\
\hline Cosmocercasp. & Hyperolius sp. 3 & 1.9 & 5.0 & - & - \\
\hline C.ornata & A. dorsalis & 2.3 & 4.0 & - & - \\
\hline \multirow[t]{5}{*}{ Foleyellides sp. } & A. dorsalis & 2.3 & 1.0 & - & - \\
\hline & H. concolor & 8.9 & $1.5 \pm 0.58$ & - & - \\
\hline & H. fusc. burtoni & 1.2 & 1.0 & - & - \\
\hline & Hyperolius sp. 1 & 4.5 & $6.0 \pm 8.66$ & - & - \\
\hline & Hyperolius sp. 3 & 1.9 & 22.0 & - & - \\
\hline \multirow[t]{3}{*}{ Physalopterasp. } & H. concolor & 4.4 & $1.5 \pm 0.71$ & - & - \\
\hline & Hyperolius sp. 1 & 3.0 & $2.5 \pm 2.12$ & - & - \\
\hline & L. spiritusnoctis & 14.3 & 6.0 & - & - \\
\hline Oxyurid nematode & Hyperolius sp. 3 & 1.9 & 36.0 & - & - \\
\hline
\end{tabular}




\section{Discussion}

High species diversity $\left(H^{\prime}=2.215\right)$ and richness $(d=1.971)$ were recorded among the tree frogs of the cocoa plantations under study, although the species were not evenly distributed. Some tree frog species, including $A$. nigeriensis, H. fusciventris, H. sylvaticus, Hyperolius spp. 2 and 4 were sparsely represented as only a single individual of each was encountered. The species number recorded (14) was however lower than the 23 recorded in the protected environment at the Okomu National Park by Imasuen et al. (2012). Furthermore, forest specialist such as Chiromantis rufescens, reported at the Gelegele Forest Reserve and the Okomu National Park was not encountered in this study, possibly due to the contaminated and altered nature of the plantation environment.

An overview of the pattern of parasitic infections in this study showed generally low prevalence and intensity of infection of the individual helminth parasites recorded. This observation is similar to earlier reports on the pattern of parasitic infections observed in leaf litter frogs (Edo-Taiwo and Aisien, 2020a) and ground dwelling amphibians (EdoTaiwo and Aisien, 2020b) collected from the same cocoa plantations. This means that irrespective of the microhabitat occupied by anurans in the cocoa plantations, the limiting effect of residual pesticide on the transmission and establishment of parasites is the same. It manifests in high parasite diversity characterized by low prevalence and infection intensity (Edo-Taiwo and Aisien., 2020a, b). An additional factor possibly responsible for the low parasite prevalence intensity is the arboreal location (habitat) of these frogs, which makes them less exposed to infection in comparison to their ground-dwelling and leaf litter counterparts. For example, at the Okomu National Park which is devoid of anthropogenic activities and pesticide contamination, prevalence/infection intensity values were equally low (Imasuen et al., 2012).

The parasite species number (13) and prevalence of infection $(30.23 \%)$ recorded among the tree frogs are marginally lower than the values ( 15 parasites $37.4 \%$ prevalence) recorded among the leaflitter frogs (Edo-Taiwo and Aisien, 2020a), but was much more lower than the 33 parasites/ $60.36 \%$ prevalence recorded among the ground dwelling amphibians (Edo-Taiwo and Aisien, 2020b). While the low infection values recorded among the leaf-litter frogs may be connected to the pesticide-contaminated environment (which impeded the development of the free-living stages of their parasites), the prevalence/ intensity of infection recorded among the tree frogs must have other causes. It can be assumed that they are isolated from parasitic stages in water and soil by their arboreal abode. Furthermore, it is possible that pesticide application may also have eliminated some arthropod vectors that could have transmitted parasites to them in this microhabitat. The immuno-suppressive effects of pesticides on the premetamorphic stages of the ground-dwelling anurans may have rendered them more susceptible to infection, hence the higher prevalence recorded in this group. Nevertheless, the infection intensity among these frogs was generally low, arising from the inhibitory effects of the pesticides on the free-living stages of parasites (Pietrock and Marcogliese, 2003) and possibly the elimination of arthropod hosts transmitting infection to these anurans.

The absence of Mesocoelium infection among the tree frogs in the cocoa plantations is noteworthy. Among the leaf-litter frogs, two unidentified Mesocoelium spp. were recorded (Edo-Taiwo and Aisien, 2020a), while among the ground dwelling anurans six tentative spp. were reported (Edo-Taiwo and Aisien, 2020b). Similarly, the tree frogs from the Okomu National Park were infected by Mesocoelium monodi and M. monas (Imasuen et al., 2012). In contrast to the frogs from these other habitats, no Mesocoelium infection was recorded in the tree frogs from the cocoa plantations. Mesocoelium spp. are transmitted by molluscan intermediate hosts (Thomas, 1965). It is presumable that pesticide action may have reduced the population of the snail intermediate hosts, thus reducing the contact between the tree frog and the snail hosts when the frogs occasionally forage for food on the plantation floor. The transmission of Ostioloides rappiae among these frogs was unaffected as infection with this digenean was recorded among four Hyperolius spp. encountered in the plantations. The intermediate host of this parasite is unknown but it can be assumed that some survived pesticide application to effect the transmission of these infections.

Parasites recovered from the tree frogs were mainly adult stages which have these frogs as definitive hosts. There were however, some larval stages which use anurans as paratenic hosts. Edo-Taiwo and Aisien (2020a) recorded Proteocephalus spp. 1 and 2 from Artholeptis spp. among the leaf-litter frogs and from some ground dwelling anurans (Ptychadena spp. Sclerophrys regularis and Aubria subsigillata). The same Proteocephalus spp. were also recovered from the tree frogs (Proteocephalus sp. 1 in Hyperolius sp. 1 and Proteocephalus sp. 2 larva from $A$. dorsalis and five Hyperolius spp.) (see Table 2). Suspected final host for these cestodes include arboreal snakes and birds. Prevalence of infection was higher in male frogs (30.75\%) than in the females $(23.53 \%)$ just as more males (322) than the females (34) were collected during the study. This is understandably so since the males make the conspecific calls which were used in locating the frogs, especially during the breeding season.

A significantly $(\mathrm{P}<0.05)$ higher prevalence of infection was recorded during the wet season $(31.64 \%)$ than in the dry $(10.53 \%)$. The wet season is the spawning season for these frogs and this activity brings them in contact with the larval stages of parasites (especially nematodes) that occur in the aquatic milieu or others that occur in other microhabitats to take advantage of the high environmental humidity to reach their hosts. Moreover, this is also the season when the arthropod intermediate host of some parasites occur in their abundance to effect their trophic transmission to their definitive hosts. This pattern of infection has also been observed by other authors (Aisien et al., 2001, 2011, 2017).

Three species of cestodes occurred in the tree frogs investigated in this study. Cylindrotaenia jaegerskioeldi (Baerietta) had a wide hosts range occurring in Leptopelis sp., Afrixalus dorsalis, $H$. fusciventris burtoni, H. picturatus, Hyperolius spp. 1 and 3. The two Proteocephalus spp. larvae recovered possibly use the tree frogs as paratenic hosts. Other researchers have also reported the occurrence of larval Proteocephalus spp. in amphibian hosts (Ulmer and James, 1976; Mckenzie, 2007; Aisien et al., 2011; Imasuen et al., 2012). According to Khalil et al. (1994), Proteocephalid cestodes have cosmopolitan distribution and species of Proteocephalus have also been recorded in freshwater fishes and reptiles (Scholz and de Chambrier, 2003).

The digenean Ostioloides rappiae was recovered only from the small intestine of Hyperolid tree frogs ( $H$. concolor, H. fusciventris burtoni, Hyperolius spp. 1 and 3). This host specificity agrees with earlier reports by other workers. This trematode was reported from the duodenum of $H$. fusciventris burtoni collected from Cote d' Ivoire (Maeder et al., 1970a). Gassmann (1975) reported it from Hyperolius nasutus, H. tuberculatus, H. viridistriatus and Scotobleps gabonicus in Cameroon. In addition to hyperolids (H. fusciventris and Hyperolius sp.), Ostioloides rappiae was reported in Afrixalus dorsalis collected 
from Okomu National Park, in Edo State, Nigeria (Imasuen and Aisien, 2012).

The other digenean recorded in this study was the metacercaria of a strigeiod trematode which occurred in high abundance. This observation contrasts with the report of King et al. (2008), which observed a decrease in the abundance of strigeoid metacercariae as a result of pesticide pollution. In the same study, King et al. (2008) also reported the presence of four non-strigeoid metacercariae (Clinostomum sp., Fibricola sp., Alaria sp. and echinostomes) from pesticide-polluted agricultural land in Canada. The occurrence of strigeiod trematodes had earlier been reported from several tree frogs (A. dorsalis, A. nigeriensis, H. fusciventris, H. picturatus, H. sylvaticus, Hyperolius sp., and Leptopelis hyloides) and P. bibronifrom the Okomu National Park and the Okomu Oil Palm Plantation in Edo State, Nigeria (Edo-Taiwo et al., 2014). Other hosts of strigeiod trematode metacercariae in Africa include D. occipitalis and $B$. regularis reported by Pike (1970) in the Sudan. Infected tree frogs serve as intermediate hosts of these trematodes for their trophic transfer to their definitive hosts (Imasuen et al., 2012; Edo-Taiwo et al., 2014), which include birds and mammals (King et al., 2010).

Nematodes were the predominant parasites among the parasites infecting the tree frogs in the cocoa plantations. Aplectana sp., Foleyellides sp. and Physaloptera sp. were generalists, infecting between three to seven anuran hosts. The microfilariae of filariid nematodes including Folleyellides are transmitted by Culex and Aedes mosquitoes to new amphibian hosts (Causey, 1939). The same observation was made by Aisien et al. (2017), who reported two Folleyellides species in the anurans investigated at Ase, a location in the Niger Delta of Nigeria. The authors remarked that the high prevalence/intensity infection of these nematodes (47.7\%/10.2 worms per infected host) bore direct relationship with the high population of mosquitoes observed in the locality. The presence of various water bodies inside the cocoa plantations must have provided good breeding ground for these mosquitoes. Adults (egg-laying females) Physalopterasp. were recovered from L. spiritusnoctis, H. concolorand Hyperolius sp. 1 in this study. This is contrary to reports of Baker (1987) and Anderson (2000), who noted that adult Physaloptera were usually parasites of reptiles, birds and mammals. Other authors (Aisien et al., 2009; Igetei, 2013; Edeigbe, 2015; Ovwah, 2016; Oseki, 2016) have similarly reported adult Physaloptera spp. in amphibians studied in southern Nigeria. Nevertheless, most records of Physaloptera in amphibians are the larval forms (Goldberg and Bursey, 2001, 2008; González and Hamann, 2007; Goldberg et al., 2009; Imasuen, 2012; Ovwah, 2016) which are thought to use amphibians as transport hosts. These parasites need further studies and characterization as they may represent new species.

Camallanus species are commonly encountered in pipid anurans (Southwell and Kirshner, 1937; Yeh, 1960; Thurston, 1970; Avery, 1971; Tinsley et al., 1979; Jackson and Tinsley, 1995, 1998) and H. occipitalis (Durette-Desset and Batcharov, 1974; Aisien et al., 2001, 2003, 2004, 2009, 2011, Igetei, 2013; Ovwah, 2016) but its occurrence in hosts like H. concolor is uncommon. Aisien et al. (2017) recorded an immature female specimen in this tree frog collected from Egbeda in Rivers State. The authors concluded that this parasite may be a new addition to the parasites that use anurans as paratenic hosts.

\section{Conclusion}

Despite pesticide use, high species diversity and richness of tree frogs were recorded in the cocoa plantations investigated in this study. However, generally low prevalence and infection intensity of helminth parasites as previously reported with leaf litter frogs and ground dwelling anurans was also observed. The low parasite prevalence/intensity of infection is indicative of the inhibitory influence of pesticides on the development and transmission of parasites in this environment.

\section{Acknowledgement}

We are grateful to Mr C. Osazee of Ugboke community and Mr Festus Arijode of the Department of Animal and Environmental Biology for their technical assistance during this investigation.

\section{References}

Aisien, S.O., Ugbo, A.D., llavbare, A.N. and Ogunbor, 0. (2001). Endoparasites of amphibians from south-western Nigeria. Acta Parasitologica. 46(4): 299-305.

Aisien, S.O., Ajakaiye, F.B. and Braimoh, K. (2003). Helminth parasites of anurans from the savannah-mosaic zone of southwestern Nigeria. Acta Parasitologica. 48(1): 47-54.

Aisien, S.O., Ayeni, F. and llechie, I. (2004). Helminth fauna of anurans from the Guinea savanna at New Bussa, Nigeria. African Zoology. 39(1): $133-136$

Aisien, S.0., Ogoannah, S.0. and Imasuen, A.A. (2009). Helminth parasites of amphibians from a rainforest reserve in Southwestern Nigeria. African Zoology. 44(1): 1-7.

Aisien, M.S.O., Nago, S.G.A. and Rodel, M.O. (2011). Parasitic infections of amphibians in the Pendjari Biosphere Reserve, Benin. African Zoology. 46(2): 340-349.

Aisien, M.S.O., Ugbomeh, A.P. and Awharitoma, A.0. (2017). Parasitic infections of anurans from a freshwater creek community in Delta state, Niger Delta of Nigeria. Helminthologia. 54(2): 132-144.

Anderson, R.C. (2000). Nematode Parasites of Vertebrates: Their Development and Transmission. $2^{\text {nd }}$ Edition CABI Publishing, Wallingford, Oxon, U.K. 560pp.

Avery, R.A. (1971). A preliminary list of parasites collected from reptiles and amphibians in Northern Nigeria. British Journal of Herpatology. 4: 217-219.

Baker, M.R. (1987). Synopsis of nematodes parasitic in amphibians and reptiles. Memorial University of Newfound-land. Occasional Papers in Biology. 11: 1-325.

Causey, O.R., (1939). Aedes and Culex mosquitoes as intermediate hosts of frog filaria, Foleyella sp. American Journal of Hygiene. 29: 79-81.

Crump, M. L. and Scott, Jr, N. J. (1994). Visual encounter surveys. In W. R. Heyer, M.A. Donnelly, R. W. McDiarmid, L. A. C. Hayek, and M. S. Foster (eds), Measuring and Monitoring Biological Diversity, Standard Methods for Amphibians, Smithsonian Institution Press, Washington DC. pp. 84-92.

David, P. (2005). Environmental and economic costs of the application of pesticides primarily in the United States. Environment, Development and Sustainability. 7: 229-252.

Durette-Desset, M-C. and Bartcharov, G. (1974). Deux Nématodes parasites d' Amphibians du Togo. Annales de Parasitologie. 49(5): 567-576.

Edeigbe, A.E. (2015). Survey of helminth parasites of amphibians (Anurans) from Ase in Delta State. B. Sc. Dissertation. University of Benin, Nigeria. 59pp.

Edo-Taiwo, O., Ovwah, E., Imasuen, A.A. and Aisien, M.S.0. (2014). Larval strigeoid trematodes in anurans from southern Nigeria. Helminthologia. 51(4): 318 - 322. 
Edo-Taiwo, 0. (2018). Amphibian diversity and parasitic infections in relation to pesticides exposure at Ugboke (plantations and settlement), Ovia South-West LGA, Edo State Nigeria. Ph.D Thesis, University of Benin. 430pp.

Edo-Taiwo, 0. and Aisien, M.S.0. (2020a). Helminth parasitic infections of leaf litter frogs (Arthroleptis and Phrynobatrachus spp.) from cocoa plantations in southern Nigeria. Nigerian Journal of Parasitology. 41(1): 93-100.

Edo-Taiwo, 0. and Aisien, M.S.O. (2020b). Parasitofauna of grounddwelling anurans from cocoa plantations in Ugboke, Edo State, Nigeria. The Zoologist, 18: 8-18.

Gassmann, M. (1975). Contribution a' l'étude des Trématodes d' Amphibians du Cameroun. Annals de Parasitologie. 50(5): 559-577.

Goater, T.M., Esch, G.W. and Bush, A.O. (1987). Helminth parasites of sympatric salamanders: ecological concepts at infracommunity, component and compound community levels. American Midland Naturalist. 118:289-300.

Goldberg, S.R. and Bursey, C.R. (2001). Helminths of the California Treefrog, Hyla cadaverina (Hylidae) from Southern California. Bulletin of Southern California Academy of Sciences. 100(2): 1-6.

Goldberg, S.R. and Bursey, C.R. (2008). Helminths from 10 species of Brachycephalid frogs

(Anura: Brachycephalidae) from Costa Rica. Comparative Parasitology. 75(2): 255-262

Goldberg, S.R, Bursey, C.R., Caldwell, J.P. and Shepard, D.B. (2009). Gastrointestinal helminths of six sympatric species of Leptodactylus from Tocantins State, Brazil. Comparative Parasitology. 76(2): 258-266.

González, C.E and Hamann, M.I. (2007). Nematode parasites of two species of Chaunus (Anura: Bufonidae) from Corrientes, Argentina. Zootaxa. 1393: 27-34.

Igetei, J.E. (2013). Parasitic infections of amphibians from the Okomu Rubber Plantation, Edo State, Nigeria. A Master Thesis, University of Benin. 130pp.

Imasuen, A.A. (2012). Investigation of the Helminth Parasitic Infections and Chytridiomycosis of Amphibians in Okomu National Park, Nigeria. Ph.D Thesis, University of Benin. 297pp.

Imasuen, A.A. and Aisien, M.S.O. (2012). Digenetic trematodes parasitic in anurans from rainforest biotopes in Edo State, Nigeria. The Zoologist. 10: 25-33.

Imasuen, A.A., Enabulele, E.E. and Aisien, M.S.O. (2012). Helminth community of tree frogs at the Okomu National Park, Edo State, Nigeria. Nigerian Journal of Parasitology. 33(1): 1-8.

Jackson, J.A. and Tinsley, R.C. (1995). Evolutionary relationship, host range and geographical distribution of Camallanus Railliet \& Henry, 1915 species (Nematoda: Camallaninae) from the clawed toads of the genus Xenopus (Anura: Pipidae). Systematic Parasitology. 32: 1-21.

Jackson, J.A. and Tinsley, R.C. (1998). Hymenochirine anurans (Pipidae) as transport hosts in Camallanid nematode lifecycles. Systematic Parasitology. 32: 141-151.

Khalil, L. F., Jones, A. and Bray, R. A. (1994). Keys to the Cestode Parasites of Vertebrates. International Institute of Parasitology, St. Albans, UK. 751pp.

Kiesecker, J.M. (2002). Synergism between trematode infection and pesticide exposure: a link to amphibian limb deformities in nature? Proceedings of the National Academy of Science United State of America. 99: 9900-9904.

King, K.C., Gendron, A.D., McLaughlin, J.D., Giroux, I., Brousseau, P., Cyr, D., Ruby, S.M., Fournier, M. and Marcogliese, D.J. (2008). Short-term seasonal changes in parasite community structure in northern leopard froglets (Rana pipiens) inhabiting agricultural wetlands. Journal of Parasitology. 94(1): 13-22.

King, K.C., Mclaughlin, J.D., Boily, M and Marcogliese, D.J. (2010). Effects of agricultural landscape and pesticides on parasitism in native bull frogs. Biological Conservation. 143(2): 302-310.

Lafferty, K.D. and Kuris, A.M. (1999). How environmental stress affects the impacts of parasites. Limnology and Oceanography. 44: 925-931.

Maeder, A.M., Combes, C. and Knoepffler, L-Ph. (1970a). Parasites d'amphibiens de Cote-d'lvoire. Plagorchidae et Mesocoeliidae (Digenea). Biologica Gabonica. 6(4): 387393.

McKenzie, V.J. (2007). Human land use and patterns of parasitism in tropical amphibian hosts. Biological Conservation. 137: 102-116.

Morley, N.J., Irwin, S.W. and Lewis, J.W. (2003). Pollution toxicity to the transmission of larval digeneans through their molluscan hosts. Parasitology. 126: 5-26.

Muzzall, P.M. (1991). Helminth infracommunities of the frogs Rana catesbeiana and Rana clamitan from Turkey Marsh, Michigan. Journal of Parasitology. 77: 366-371.

Oseki, C.B. (2016). A survey of helminth parasites of amphibians in Ikpako, Ovia South West Local Government Area, Edo State. B. Sc Dissertation. University of Benin, Nigeria. 59pp.

Ovwah, E. (2016). Amphibian diversity and helminth parasitic infections of anurans at Okomu Oil Palm Plantations, Okomu-Udo, Edo State, Nigeria. Ph.D Thesis. University of Benin, Nigeria. 285pp.

Pietrock, M. and Marcogliese, D.J. (2003). Free-living endohelminth stages: at the mercy of environmental conditions. Trends in Parasitology. 19: 293-299.

Pike, A.W. (1970). Helminth parasites of the amphibians Dicroglossus occipitalis (Gunther) and Bufo regularis Reuss, in Khartoum, Republic of Sudan. Journal of Natural History. 13: 337-376.

Prudhoe, S. and Bray, R.A. (1982). Platyhelminth Parasites of the Amphibia. British Museum (Natural History), Oxford University Press, London. 217pp.

Röedel, M.O. (2000). Herpetofauna of West African. Amphibians of the West African Savanna (Vol. 1) Edition Chimaira, Frankfurt, pp. 332.

Röedel, M.O. (2007). The identity of Hylambates hyloides Boulenger, 1906 and description of a new small species of Leptopelis from West Africa. Mitteilungen aus dem Museum fur Naturkunde Berlin Zoologische Reihe. 83: 90-100.

Rohr, J.R., Schotthoefer, A.M., Raffel, T.R., Carrick, H.J., Halstead, N., Hoverman, J.T., Johnson, C.M., Johnson, L.B., Lieske, C., Piwoni, M.D., Schoff, P.K. and Beasley, V.R. (2008. Agrochemicals increase trematode infections in a declining amphibian species. Nature. 455: 1235-1239.

Schiotz, A. (1963). The amphibians of Nigeria. VidenskabeligeMeddelelser fra Dansk Naturhistorisk Forening. 125: 1-92.

Schiotz, A. (1999). Tree frogs of Africa. Edition Chimaira, Frankfurt, pp. 350 . 
Scholz, T. and de Chambrier, A. (2003). Taxonomy and biology of proteocephalid cestodes : current state and perspectives. Helminthologia 40(2): 65-77.

Southwell, T. and Kirshner, A. (1937). On some parasitic worms in Xenopus laevis, the South Africa clawed toad. Annals of Tropical Medicine and Parasitology. 31: 245-265.

Thomas, J.D. (1965). The anatomy, life history and size allometry of Mesocoelium monodiDollfus, 1929. Journal of Zoology 146: 413-446.

Thurston, J.P. (1970). Studies on some protozoans helminth parasites of Xenopus, the African clawed toad. Revue de Zoologieet de Botanique Africaines. 82: 349-369.
Tinsley, R.C., Kobel, H.R., and Fischberg, M. (1979). The biology and systematic of a new species of Xenopus (Anura: Pipidae) from the highlands of central Africa. Journal of Zoology London. 188: 69-102.

Ulmer, M.J. and James, H.A. (1976). Studies on the Helminth fauna of lowa. II. Cestodes of Amphibians. Proceedings of the Helminthological Society of Washington. 43(2): 191-200.

Yamaguti, S. (1961). Systema Helminthum. Volume III. The nematode of vertebrates part II. Interscience Publishers, Inc., New York. $1261 \mathrm{pp}$.

Yamaguti, S. (1971). Synopsis of Digenetic Trematodes of Vertebrates.Vol.I. Keigaku Publ. Co., Tokyo. 530pp.

Yeh, L.S. (1960). On Camallanus johnisp. nov. collected from Xenopus in Tanganyika Territory. Journal of Helminthology. 34: 103106. 